\title{
Disciplinary Literacies Across Content Areas: Supporting Secondary Reading Through Functional Language Analysis
}

\section{By making discipline-specific}

ways of using language

explicit, teachers can help

adolescents better engage

with school knowledge and

more effectively develop

disciplinary literacies across

academic content areas.
Zhihui Fang | Mary J. Schleppegrell

$\mathrm{T}_{\mathrm{h}}$ he challenges involved in meeting the literacy demands of secondary schooling are currently a major focus of discussion (e.g., Ippolito, Steele, \& Samson, 2008). Recent reports (e.g., Perie, Grigg, \& Donahue, 2005) suggest that too many adolescents lack the literacy skills necessary to succeed in secondary schooling, with well over 8 million students in grades 4-12 struggling to comprehend texts in academic content areas. Leading literacy organizations and researchers (Alvermann, 2001; Biancarosa \& Snow, 2004; Heller \& Greenleaf, 2007; Moore, Bean, Birdyshaw, \& Rycik, 1999) have called for greater attention to adolescent literacy, urging educators to provide instructional support for adolescents as they interact with academic texts in curricular content areas. They emphasize that reading success in the early grades is not the end of the story and that middle and high school students need to develop more advanced levels of literacy to learn effectively from the more specialized, complex texts of secondary subjects. As the Carnegie Corporation (2003) noted in its rationale for establishing a new research funding program on adolescent literacy, "The way in which students are taught to read, comprehend and write about subject matter has not kept pace with the [new] demands of schooling" (p. 2). Together, these reports recognize that the texts of secondary schooling pose new demands and that students need to develop new capacities for coping with these challenges.

But what should secondary reading instruction be the instruction of? Cognitive strategies (e.g., predicting, inferring, think aloud, visualizing), vocabulary, fluency, phonics, and phonological awareness are the staples of popular reading programs for middle and high schools (see Alvermann \& Rush, 2004, for a review). But this emphasis on the strategies and skills that are the mainstay of elementary reading instruction fails to recognize the significant differences in reading demands that emerge in secondary schooling. Major secondary reading textbooks (e.g., Alvermann, Phelps, \& Gillis, 2010; Brozo \& Simpson, 2006; Vacca \& Vacca, 2005) and popular teacher professional development materials (e.g., Beers, 2002; Harvey \& Goudvis, 2007; Keene \& Zimmermann, 2007; Tovani, 2000) also focus on these and other strategies—such as note 


\section{Students need to develop the ability \\ to "handle language \\ in new ways" to \\ effectively engage \\ with educational \\ knowledge at the \\ secondary level.}

taking, summarizing, determining main ideas, and identifying facts versus opinions - many of which are oriented more toward demonstrating comprehension than learning to comprehend. Where a focus on language itself is suggested, as in the analysis of text structure commonly recommended in secondary content area reading textbooks, students are encouraged to use signal words (e.g., for example, however) to recognize generic structures such as listing, description, explanation, sequence, compare and contrast, cause and effect, or problem and solution, but the focus on language is not comprehensive, and the target expressions are often not found in the actual texts students read.

This focus on generalized literacy strategies has been criticized by Moje and Speyer (2008), who drew a distinction between strategies and practices, suggesting that we need to consider the larger contexts in which strategies are taken up and the practices that various strategies support. In addition, Moje (2008) suggested that "it may be most productive to build disciplinary literacy instructional programs, rather than to merely encourage content teachers to employ literacy teaching practices and strategies" (emphasis original, p. 96). She called for a secondary reading pedagogy that "builds an understanding of how knowledge is produced in the disciplines, rather than just building knowledge in the disciplines" (p. 97).

Supporting the development of disciplinary literacy, from this perspective, requires content area teachers to foster students' engagement in practices that provide them with opportunities to gain access to knowledge as well as opportunities to engage in critique of new knowledge and disciplinary practices. One important way that disciplinary knowledge and opportunities for critique are made available to students is through the reading of disciplinary texts. Moje and Speyer (2008), for example, described how a teacher's close reading of even small portions of text with students "helped to maintain their engagement" (p. 197) and recommended that teachers model the reading of disciplinary texts in interaction with students.
In this article, we describe an approach to close reading that draws on functional linguistic perspectives to offer ways of engaging students in exploring meaning in content area texts. The approach, called functional language analysis (Fang \& Schleppegrell, 2008), provides a metalanguage for talking about the meaning in the choices authors make as they write clauses, sentences, and texts. Functional language analysis enables students to identify language patterns and associated meanings specific to particular disciplines as they focus on how language works, helping them comprehend and critique the texts of secondary content areas. It recognizes that as the knowledge students have to learn becomes more specialized and complex, so does the language that constructs such knowledge (Halliday, 2007; Schleppegrell, 2004). This means that students need to develop the ability to "handle language in new ways" (Christie, 1998, p. 57) to effectively engage with educational knowledge at the secondary level.

\section{Language and Literacies Across Secondary Content Areas}

The academic texts of secondary content areas are constructed in language patterns that differ from the more everyday ways of using language that characterize the texts elementary students typically read. These language patterns are often unfamiliar to adolescents and present significant comprehension challenges. Let's compare the following two texts.

\section{Text 1}

That night, I had an uneasy sleep. Strange noises emanated from downstairs. It sounded like toenails clicking back and forth on the floor. It must be Bunnicula making his midnight run, I thought, although I'd never known him to make a sound. And I smelled the funniest odor in the air-something familiar, though I couldn't place it. As the night progressed, it grew stronger and stronger until finally it tickled my nose and I sneezed myself awake. I jumped off Toby's bed, still sniffling, and headed down the stairs for the living room to find Chester, to see if he could smell it, too. (Howe \& Howe, 1979, p. 62)

\section{Text 2}

Organisms made up of one or more cells that have a nucleus and membrane-bound organelles are called eukaryotes. Eukaryotic cells also have a variety of 
subcellular structures called organelles, well-defined, intracellular bodies that perform specific functions for the cell. (Modern Biology, 2006, p. 75)

Text 1 is an excerpt from Deborah and James Howe's (1979) Bunnicula, an immensely popular and humorous children's story. It represents the kinds of texts that constitute elementary students' main literacy staples. The text is about a dog (Harold) and a cat (Chester) who become convinced that the new pet (Bunnicula) in the Monroe family is a vampire bunny. This topic is of high familiarity and interest to students as they are often exposed to fantasy stories in the early years of schooling. The text uses nontechnical vocabulary and simple clauses that are linked into sentences through coordination (and) or subordination (as, although, until). The language of the text thus captures the dynamism and fluidity of speech, resembling the story-telling language with which students are familiar. The language of secondary science, history, and mathematics, on the other hand, tends to have technical and abstract vocabulary and sentences made up of embedded clauses that create a dense and compacted presentation of information.

Text 2 is an excerpt from Modern Biology (2006), a 10th-grade biology textbook. It deals with a specialized topic, eukaryotes, and uses language patterns that are distinct from those used in Text 1 . Text 2 contains a heavy load of technical vocabulary (organisms, nucleus, cells, membrane, organelles). Its sentences contain embedded clauses that form long noun phrases. For example, the first sentence contains two embedded clauses (made up of one or more cells; that have a nucleus and membrane-bound organelles) that compact information about the head noun (organisms) in a dense noun phrase serving as the subject of the sentence that defines the technical concept eukaryotes. The second sentence also contains a long noun phrase, "a variety of subcellular structures called organelles," which is further expanded through another long noun phrase with an embedded clause, "well-defined, intracellular bodies that perform specific functions for the cell." In essence, the content of Text 2 is densely packed in noun phrases that are then linked together by relating verbs (are called, have) to enable the construction of technical definitions and description of biological processes. This way of presenting information is different from that in Text 1 , where nouns are generally short and simple (Chester, it, $I$ ) and the content of the text is loosely strung out in clauses that are intricately linked.

Not only does the technical, dense language of secondary science contrast sharply with the more commonsensical, dynamic language that is typical of elementary storybook texts, it also differs in some significant ways from the discourses of other secondary content areas. Text 3, for example, is an excerpt from Behr's (1996) Prohibition: Thirteen Years That Changed America.

\section{Text 3}

In retrospect, the Volstead Act was hopelessly inadequate, because it grossly underestimated the willingness of the lawbreakers to risk conviction, the degree of human ingenuity displayed to get around its provisions, and the ease with which the lawbreakers would be able to subvert all those whose job was to enforce it. Above all, its failure resulted from a naïve American belief in the effectiveness of law. (p. 79)

This excerpt explains reasons for the failure of the Volstead Act, legislation that prohibited the sale and consumption of alcohol from 1920 to 1933. Along with the technical term "the Volstead Act," this text is populated with nominalizations-that is, nouns derived from verbs or adjectives-such as willingness, conviction, ingenuity, provision, the ease, failure, belief, and effectiveness. These nominalizations repackage processes (normally expressed by verbs) and qualities (normally expressed by adjectives) into things (expressed in nouns). They help create a world of abstractions, different from the world of action and feeling depicted in Text 1 and the world of technicality and density conveyed through Text 2 . They enable the author to bundle together events over time into a package (the Volstead Act), to ascribe judgment (hopelessly inadequate), to infuse perspectives (a naïve American belief), to efface agency (conviction), to quantify concepts (the degree of human ingenuity), and to expand information (the ease with which the lawbreakers would be able to subvert all those whose job was to enforce it). The ideological motif that "the Volstead Act is bad policy" is foregrounded through language choices that have clear evaluative connotations. 
While nominalization is frequent in history texts, it is not unique to history; in fact, it occurs in all secondary school subjects (Fang \& Schleppegrell, 2008). However, it serves different functions in different subjects (Halliday \& Martin, 1993). In science, for example, nominalization tends to occur in explanations and reports because it helps accumulate meanings so that a technical term can be defined or used to sum up an explanation sequence. In history, on the other hand, nominalization is more often used to realize events as things so that historians can develop a chain of reasoning that at the same time embeds interpretation and judgment. These ways of using language can render texts abstract and alienating, making it difficult for students to comprehend and uncover hidden meanings.

Another feature of the language of secondary school texts is multimodality. In all subjects, students need to recognize the meanings made in both language and visual elements, and in the interaction of these modalities. In mathematics, however, there is an additional challenge, that of working with texts that are multisemiotic. Mathematical texts draw on two different "languages"-natural language and mathematics symbolic language-in conjunction with visual representation through graphs, diagrams, and other visual elements (O'Halloran, 2005). Text 4 is a geometry word problem for 11th grade (www.stfx .ca/special/mathproblems/grade11.html). While word problems do not fully illustrate the challenges of reading mathematics, they represent a high-stakes context in which students need to demonstrate mathematics knowledge, and teachers need strategies for helping students unpack the dense clauses they typically use.

\section{Text 4}

If a rectangular solid has side, front and bottom faces with areas of $2 x, y / 2$ and $x y \mathrm{~cm}^{2}$ respectively, what is the volume of the solid in centimeters cubed? (problem 33)

To solve this problem, students need to understand not only the technical words such as rectangular, centimeters, and cubed but also everyday words that take on particular meanings in mathematics (solid, faces, areas). But vocabulary is only part of the linguistic challenge in mathematics. Technical vocabulary works with other grammatical elements to construct mathematical meanings that can be both dense and technical. For example, mathematical meanings in Text 4 are also constructed in two long noun phrases- "side, front and bottom faces with areas of $2 x, y / 2$ and $x y$ $\mathrm{cm}^{2}$ respectively" and "the volume of the solid in centimeters cubed." In the first noun phrase, the head noun (faces) has premodifiers (side, front, and bottom) and postmodifiers (with areas of $2 x, y / 2$ and $x y \mathrm{~cm}^{2} \mathrm{re-}$ spectively). At the same time, this noun phrase presents information that in an expanded form would require several mathematical processes (expressed in relating verbs be and have) to be made explicit: A rectangular solid has 6 faces; they are side (left and right) faces, front and back faces, and top and bottom faces; the area of each of the side faces is $2 x \mathrm{~cm}^{2}$; the area of the front (or back) face is $\gamma / 2 \mathrm{~cm}^{2}$; and the area of the bottom (or top) face is $x y \mathrm{~cm}^{2}$.

In the second long noun phrase, the head noun (volume) has a premodifier (the) and two postmodifiers expressed in prepositional phrases (of the solid, in centimeter cubed). It can likewise be seen as condensation of several mathematical processes: the solid has volume, the volume can be measured, and the unit for measuring the volume must be in cubic centimeter. Students have to learn to recognize how language repackages the processes of mathematics reasoning as in these complex noun phrases.

Conjunctions such as the if here, which construes a hypothetical condition, are used in precise and technical ways in mathematics, unlike in everyday language where conjunctions such as if, when, and so are often used in vague and imprecise ways (Schleppegrell, 2004). And understanding natural language is not sufficient in solving the problem. Students must also be knowledgeable about the mathematical symbolism, such as $x, y, y / 2$, and $\mathrm{cm}^{2}$, developed to represent mathematical constructs and relationships between mathematical entities that cannot be presented with the same precision and ease in natural language.

Students also have to be able to translate the information in the word problem into a visual display, as in the rectangular prism presented in Figure 1. This visual display provides a connection between the abstract mathematical processes constructed in the word problem and the tangible material world represented 
in the geometric figure. Without the visual display, it would be difficult to come up with the solution to the problem, which is length $\times$ width $\times$ height, or $(2 x) \mathrm{x}$ $(y / 2) \times 1=x y \mathrm{~cm}^{3}$.

The previous sample texts demonstrate that academic texts in secondary content areas are constructed in characteristic patterns of language that present new forms, purposes, and processing demands. These new language patterns are not just complexities that construct barriers to privilege content experts; rather, they have evolved to meet the needs of particular disciplines. While the language that constructs secondary science, history, and mathematics texts shares some common features (e.g., technical, dense, abstract) that render it recognizable as academic, these features are patterned grammatically in different ways across different academic subjects because of disciplinary differences in epistemologies and social practices. As Shanahan and Shanahan (2008) noted, disciplines differ in how they produce, communicate, and evaluate knowledge, and these differences are manifested in how subject experts use language. In science, for example, what we recognize as scientific is typically construed in language patterns that enable the development of chains of reasoning that are technical and dense. In history, language presents interpretation at the same time it offers accounts of the past, and recognizing how abstraction and nominalization work can enable students to see ideologies and values in grammatical constructions that elide agency or conflate time and cause. Mathematical discourse is simultaneously technical, dense, and multi-semiotic, drawing on natural language, symbolic language, and visual display, which interact in discipline-specific, synergistic ways.

Given the distinct ways different academic subjects use language to construct meanings, adolescent learners must develop differentiated literacy skills and strategies for interacting with disciplinary texts. Because subject specialists are best positioned to apprentice students into meaning-making in their disciplines, this literacy development work cannot be left to the reading or language arts teacher alone. All teachers need to be able to demonstrate and make visible to students how literacy operates within their disciplines, helping adolescents learn how content

\section{Figure 1 Rectangular Prism}

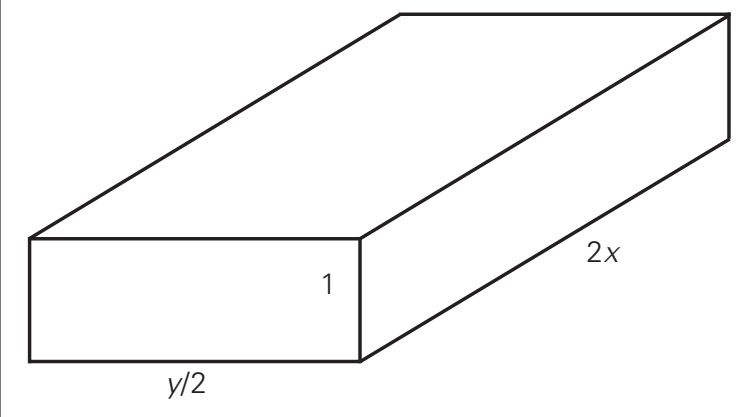

experts use language in characteristic ways to present information, engage in interpretation, and create specialized texts. Functional language analysis offers a means of engaging students in analysis of text in an interactive way, providing opportunities for close reading and discussion about how an author has presented knowledge and the particular perspectives on knowledge that are typical of each discipline.

\section{Functional Language Analysis: What Is It?}

Functional language analysis (Fang \& Schleppegrell, 2008) is an approach to secondary content area reading grounded in systemic functional linguistics (SFL; Halliday, 1994). SFL is a social semiotic theory that sees language as a resource for making meaning in context, where the language choices reflect and enact the context and the context predicts or suggests the language that will be used. Speakers and writers make (typically unconscious) choices from the various options that language makes available, according to the social and cultural contexts in which meaning is exchanged. As an interlocking set of grammatical systems, language enables its users to make different kinds of meaning for different purposes and contexts. Thus, variations in language patterns express the diversity of structures and processes in the social system. Helping learners recognize language patterns typical in different disciplines can raise their awareness about the varied ways language constructs knowledge in different subjects.

SFL offers a three-way perspective on language that is useful for exploring meaning in texts of 
different types, as every use of language, whether spoken or written, can be analyzed for what it says about the world (the experiential meaning), for the social relationship it enacts (the interpersonal meaning), and for the way it weaves meanings into a coherent message (the textual meaning). Functional language analysis draws on the metalanguage - the language for talking about language - provided by SFL to support exploration of each of these perspectives on meaning by analyzing the language an author has used. It thereby offers teachers an array of analytical tools for engaging in discussion of text in ways that make explicit how meaning is constructed.

From the perspective of experiential meaning, the human experience represented in language, each clause presents a process with attendant participants and circumstances. Functional language analysis recognizes four major types of processes-doing (realized by action verbs like perform and calculate), sensing (realized by thinking and feeling verbs like think and fear), being (realized by relating verbs like be and have), and saying (realized by talking verbs like say and speak). Processes involve people or things (called participants), typically realized in noun phrases (e.g., Chester, it, a variety of subcellular structures called organelles, conviction), and these participants take on different semantic roles in different process types (as actors, sayers, etc.). Processes also take place in certain time, space, and conditions (called circumstances), typically realized in adverbs (e.g., finally, respectively) or prepositional phrases (e.g., in retrospect, above all). Analysis of process types, participants, and circumstances in clauses can thus reveal what is going on in the text.

Interpersonal meaning is concerned with the ways relationships are enacted among people and their opinions and attitudes. It can be explored in the mood and modality systems of language. The mood system allows us to make statements (normally expressed in declarative mood), ask questions (normally expressed in interrogative mood), and issue commands (normally expressed in imperative mood). The modality system allows us to construe possibility, certainty, normality, seriousness, necessity, and obligation. Modal verbs (e.g., should, might, ought to), modal adjectives (e.g., definite, absolute, usual), modal adverbs (e.g., perhaps, certainly, typically), and modal nouns (e.g., requirement, necessity), along with attitudinal vocabulary, enable us to construe stance, judgment, and evaluation. Analysis of the language used to enact these interpersonal meanings can thus help readers gain insights into how an author positions and persuades readers in particular ways, an understanding that is important to the development of critical literacy.

Textual meaning, the way we organize information in a text and make connections across the text, is realized through the linguistic systems of theme/ rheme and cohesion. Clauses in English text typically begin with something that is familiar or already known to the reader (the theme) and then move on to present something new (the rheme). Cohesion refers to the way a text hangs together with the help of linguistic devices such as pronouns (e.g., it, this, we), synonyms and antonyms (e.g., carnivore/meat eater, adequate/inadequate), and conjunctions (e.g., although, above all, for example). Analysis of the theme/rheme structure and cohesion helps us see how a text is organized and how information flows in a text.

Every text (and every clause) simultaneously presents these three strands of meaning, as the grammatical systems of language enable the text (and clause) to mean what it does. Teachers and students can engage in a functional analysis of language patterns to explore meaning in the text. For example, to explore what is going on in a text (e.g., who does what to whom, how, when, and where), we can analyze the process types, participants, and circumstances that an author has chosen. If we are interested in how a text is organized, we can examine the theme/rheme structure and cohesion in the text, focusing on ways in which the author calibrates information flow and builds up an argument. If we are concerned with how the author interacts with the reader or the author's perspective in the text, we can analyze the mood and modality systems of language as well as word choices. Table 1 shows the kinds of functional language analysis strategies that can be used to answer key comprehension questions typically asked about text in school.

\section{Functional Language Analysis in the Classroom}

Using Table 1 as a guide, let's read Text 5, an excerpt from a middle school science textbook (Science 


\begin{tabular}{|c|c|c|}
\hline Questions about text & Types of meaning & Functional language analysis strategies \\
\hline $\begin{array}{l}\text { Content: What is going on in this text? } \\
\text { Who does what to whom, how, when, and } \\
\text { where? }\end{array}$ & Experiential meaning & $\begin{array}{l}\text { Analyze process types with accompanying } \\
\text { participants and circumstances }\end{array}$ \\
\hline \multirow[t]{2}{*}{ Organization: How is this text organized? } & \multirow[t]{2}{*}{ Textual meaning } & Analyze clause themes \\
\hline & & $\begin{array}{l}\text { Analyze cohesive devices such as pronouns } \\
\text { and conjunctions }\end{array}$ \\
\hline \multirow{3}{*}{$\begin{array}{l}\text { Style/voice: How does the author of this } \\
\text { text interact with the reader? What is the } \\
\text { author's perspective? }\end{array}$} & \multirow[t]{3}{*}{ Interpersonal meaning } & Analyze mood \\
\hline & & Analyze modality \\
\hline & & Analyze word choices \\
\hline
\end{tabular}

Explorer, 2001), and explore how functional language analysis can be used in the classroom to help us construct meaning by answering the three key comprehension questions about the text.

\section{Text 5}

If some people inhale a substance to which they are allergic, they may develop a condition called asthma. Asthma (az muh) is a disorder in which the respiratory passages narrow significantly. This narrowing causes the person to wheeze and become short of breath. Asthma attacks may be brought on by factors other than allergies, such as stress and exercise. Severe asthma attacks may require emergency medical care. People who have asthma can prevent asthma attacks with medication, or they can avoid the substances and activities that trigger attacks. (p. 613)

This text is in a chapter called "Fighting Disease." It occurs in a section called Noninfectious Disease, the last of four sections, following study of the topics Infectious Disease, The Body's Defenses, and Preventing Infectious Disease. In the section where the paragraph occurs, students explore what happens when airflow to their lungs is restricted. This paragraph follows paragraphs that define allergies. A major project in the chapter is that students research a specific disease, learn how it affects the body and how the body responds, and then prepare "news reports" on it. The teacher decides to use this paragraph about asthma to model for students how they can read the often dense and information-packed descriptions of diseases that they will encounter in their research.

Having already developed with students the metalanguage of functional language analysis (constructs including theme, rheme, process, participant, circumstance, conjunction, and terms associated with different process types), and having reviewed the text himself to identify what the analysis can offer, the teacher engages the students in discussion about how the author has constructed the text, focusing them on how they can unpack the dense meanings.

First, to explore what is going on in the text, the teacher asks students to identify any being processes. The students point to this sentence (the third clause in the text): "Asthma (az muh) is a disorder in which the respiratory passages narrow significantly." The teacher points out that being processes (realized in relating verbs such as is) present definitions and descriptions, and students can look for them in the texts they will be reading to zero in on how the author is defining the disease they are reading about. In this definition, typical of science, the dense noun phrase "a disorder in which the respiratory passages narrow significantly" defines asthma. Isolating this sentence leads the class into discussion about the meaning of disorder in this context, as well as what it means for respiratory passages to narrow significantly. The students are learning that in scientific English, definitions are often constructed in lengthy noun phrases that enable the author to compact a large quantity of information 
into the nominal structure so as to ensure precision, accuracy, and conciseness.

The teacher then asks the students what other kinds of processes they see in the text, and the students find that the main process type that the author has used is processes of doing. The students then explore who the author has represented as "actors" in this passage and what it is that they do. Table 2 sets out the analysis the students construct, using metalanguage that identifies the clause constituents - process (doing), participants (as actors or goals), and circumstance. In looking at what their deconstruction of the text has revealed, the students see that the author has presented not only people as actors but also the causes of asthma and the asthma attacks themselves. They see that the author has described the causes and effects of asthma, and what people can do to prevent it. The teacher draws their attention to the wording of the circumstance in clause seven, "with medication," pointing out that the phrase itself also involves someone doing something (taking medicine), but that the author has presented this idea in an abstraction, typical of science text.

Analyzing the clauses this way and discussing the process types and attendant participants and circumstances and how they contribute to the meaning helps students focus on the information that the text provides, but it also helps them better recognize how English works in a text like this. In exploring this text and developing the list of actors and their goals, the students find that they have to rearrange the order of elements in some sentences. For example, the sentence "Asthma attacks may be brought on by factors other than allergies, such as stress and exercise" is in passive voice, and so recognizing what is doing what requires close reading to see that the actors in this sentence are presented in the by phrase (by factors other than allergies, such as stress and exercise). The students learn to look for the meaning in the sentence and while doing their analysis have animated discussions about what each sentence means, who the actors are, and how their goals are presented. In preparing Table 2 , in some cases the students need to change the tense of the verbs in order for the rearranged elements to make sense (e.g., wheezes and becomes short of breath, may bring on). They also need to recognize that "this narrowing" in the third sentence of text 5 is an abstraction that functions as the agent that causes wheezing and becoming short of breath. All of this discussion and analysis both supports their comprehension of the passage and shows them how the English language works.

The discussion about the ordering of elements in the text motivates a discussion about how the author has organized the text, another question that a functional language analysis can illuminate. To explore this, and to help the students read other texts with lots of information densely packed, the teacher

Table 2 Analysis of Doing Processes in Text 5

\begin{tabular}{|c|c|c|c|c|}
\hline Clause & Participant (actor) & "Doing" process & Participant (goal) & Circumstance \\
\hline 1 & some people & inhale & $\begin{array}{l}\text { a substance to which they } \\
\text { are allergic }\end{array}$ & \\
\hline 2 & they & may develop & a condition called asthma & \\
\hline 4 & the person & $\begin{array}{l}\text { wheezes and becomes } \\
\text { short of breath }\end{array}$ & & \\
\hline 5 & $\begin{array}{l}\text { factors other than allergies, } \\
\text { such as stress and exercise }\end{array}$ & may bring on & Asthma attacks & \\
\hline 6 & Severe asthma attacks & may require & emergency medical care & \\
\hline 7 & People who have asthma & can prevent & asthma attacks & with medication \\
\hline 8 & they & can avoid & $\begin{array}{l}\text { the substances and activities } \\
\text { that trigger attacks }\end{array}$ & \\
\hline
\end{tabular}


asks his students to explore the choices the author has made in terms of theme/rheme structuring, looking at how clauses begin and end, and at the relationship between the beginnings and endings. The theme is the point of departure for the clause and the rheme provides the new information that the author is developing. The students then develop a visual display like that in Figure 2.

The visual display highlights the fact that the author begins and ends the paragraph with people as the point of departure in the themes; but after beginning with a focus on people, the text shifts to focus on the disease (asthma, this narrowing, asthma attacks). Analyzing the themes allows the students to see that the author of the text is mainly concerned with asthma and people who have asthma, as those are the points of departure around which the message of each clause is organized. The students also recognize the typical flow of information in a science text, where an author often repackages information in the rheme of one clause in a technical term or nominalization that then serves as the theme of the following clause. For example, the theme of clause four, the abstraction "this narrowing", repackages the information in the rheme of the previous clause (in which the respiratory passages narrow significantly). Similarly, the rheme of the fourth clause (causes the person to wheeze and become short of breath) is synthesized into "asthma attacks" in the theme of clause five. This analysis also explains the use of passive voice in clause five. Since asthma attacks has been used as the theme, and yet the author wants to tell us what causes the attacks, this has to be done with the by phrase. In other parts of the text, the same theme is repeated, via synonyms or pronouns, across several clauses (as in clauses one and two, clauses five and six, and clauses seven and eight), enabling the author to add information about asthma attacks and about people who have asthma attacks.

Finally, the teacher asks the students to find the language in the text that reveals aspects of the perspective the author has incorporated by exploring mood, modality, and word choices. The students notice that the entire text is presented in declarative mood (no questions or commands). This suggests that the author is positioned as an expert who presents information in an authoritative and assertive manner. But the students also notice that not every statement is presented as a statement of fact. The first sentence presents a

\footnotetext{
Figure 2 Theme/Rheme Structure of the Asthma Text

Clause Theme Rheme

$1 \quad$ If some people inhale a substance to which they are allergic<smiles>C[14CH2]</smiles>

they may develop a condition called asthma

3

Asthma is a disorder in which the respiratory passages narrow significantly.

4

This narrowing causes the person to wheeze and become short of breath.

5

Asthma attacks

may be brought on by factors other than allergies, such as stress and exercise.<smiles>C[Te]</smiles>

6

Severe asthma attacks may require emergency medical care.

7

People who have asthma can prevent asthma attacks with medication,

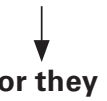

can avoid the substances and activities that trigger attacks.
} 
condition (if) and the notion of possibility rather than certainty (may develop), and this is said to apply to "some people," not all. In fact, may is also used in clauses five and six, and the students conclude that this is because the author wants to be accurate in the information presented, as asthma attacks have different sources and not all severe asthma attacks require emergency medical care. The last two clauses of the text make recommendations for how people can avoid asthma attacks. While the advice could have been issued as commands (e.g., Take medicine to prevent asthma), the author instead presents recommendations using the modal verb of ability (can) to suggest what people can do. Overall, the students conclude that the author is using a typical medical style that is formal and precise.

\section{Beyond Basic Skills and Strategies}

Secondary years are a time when students are "potentially very aware of language, and receptive to new ways of exploring and exploiting it" (Halliday, 2007, p. 62). Using functional language analysis, students simultaneously learn through language and about language, better comprehending the text at the same time they gain a better understanding of how language is used to present content, infuse perspectives, and organize specialized texts.

Functional language analysis offers practical strategies for talking about text through detailed analysis of language and accompanying discussion about the meanings of the language patterns. Teachers and students can enjoy using this approach to explore the meaning an author has constructed in a text through the language choices. Teachers in different subject areas can use the three-dimensional focus-on how experiential, interpersonal, and textual meanings are constructed in the grammatical patterns of languageto highlight disciplinary knowledge and values in ways that give students access to subject-specific ways of making meaning through language. By helping students see how meaning is presented through language in their disciplines, teachers enable students to become independent readers who can not only comprehend but also reflect in critical ways on what they read.

Functional language analysis can be used in reading segments of textbooks, trade books, primary source documents, and other texts where grammatical analysis can help students construct meaning from unfamiliar and challenging language patterns. Its focus is not on analysis for its own sake, but analysis to get at meanings so that students learn content at the same time they develop critical thinking skills. Used in conjunction with activities that engage the reader's background knowledge and experiences, functional language analysis can be embedded in a sequence of classroom activities in which students listen, talk, interact, and inquire in a coherent unit of instruction. As students read content area texts, engaging in functional language analysis helps them recognize how the particular language choices give the text its meaning potential. By deconstructing and talking about challenging texts with the guidance of a knowledgeable teacher, students begin to see how content experts use language to present meaning in discipline-specific ways.

As educational knowledge becomes more specialized and removed from students' everyday experiences, the language that constructs such knowledge also becomes more technical, dense, abstract, and complex, patterning in ways that enable content experts to engage in specialized social and semiotic practices. This means that each secondary subject has specialized ways of using language that may pose comprehension challenges to adolescents. The basic reading skills and generalizable strategies that students learn in the elementary school are inadequate in preparing them for these new challenges. Functional language analysis offers an approach to secondary reading that recognizes the role of language in construing knowledge and value and enables teachers to help students recognize the specialized patterns of language in the texts they read. By making discipline-specific ways of using language explicit, teachers can help adolescents, especially those who have little access to these ways of making meaning outside of school, better engage with school knowledge and more effectively develop disciplinary literacies across academic content areas.

\section{References}

Alvermann, D.E. (2001). Effective literacy instruction for adolescents. Journal of Literacy Research, 34(2), 189-208.

Alvermann, D.E., Phelps, S.F., \& Gillis, V.R. (2010). Content area reading and literacy: Succeeding in today's diverse classroom (6th ed.). Boston: Allyn \& Bacon. 
Alvermann, D.E., \& Rush, L.S. (2004). Literacy intervention programs at the middle and high school levels. In T.L. Jetton \& J.A. Dole (Eds.), Adolescent literacy research and practice (pp. 210-217). New York: Guilford.

Beers, G.K. (2002). When kids can't read, what teachers can do: A guide for teachers 6-12. Portsmouth, NH: Heinemann.

Biancarosa, G., \& Snow, C.E. (2004). Reading Next: A vision for action and research in middle and high school literacy: A report from Carnegie Corporation of New York. Washington, DC: Alliance for Excellent Education.

Brozo, W.G., \& Simpson, M.L. (2006). Content literacy for today's adolescents: Honoring diversity and building competence (5th ed.). Upper Saddle River, NJ: Prentice Hall.

Carnegie Corporation (2003). Advancing literacy. Retrieved January 24, 2009, from www.carnegie.org/literacy/index .html

Christie, F. (1998). Learning the literacies of primary and secondary schooling. In F. Christie \& R. Misson (Eds.), Literacy and schooling (pp. 47-73). London: Routledge.

Fang, Z., \& Schleppegrell, M.J. (2008). Reading in secondary content areas: A language-based pedagogy. Ann Arbor, MI: University of Michigan Press.

Halliday, M.A.K. (1994). An introduction to functional grammar (2nd ed.). London: Edward Arnold.

Halliday, M.A.K. (2007). Some thoughts on language in the middle school years. In J.J. Webster (Ed.), Language and education (Vol. 9, pp. 49-62). London: Continuum.

Halliday, M.A.K., \& Martin, J.R. (1993). Writing science: Literacy and discursive power. Pittsburgh, PA: University of Pittsburgh Press.

Harvey, S., \& Goudvis, A. (2007). Strategies that work: Teaching comprehension for understanding and engagement. Portland, ME: Stenhouse.

Heller, R., \& Greenleaf, C.L. (2007). Literacy instruction in the content areas: Getting to the core of middle and high school improvement. Washington, DC: Alliance for Excellent Education.

Ippolito, J., Steele, J.L., \& Samson, J.F. (2008). Introduction: Why adolescent literacy matters now. Harvard Educational Review, 78(1), 1-6.

Keene, E.O., \& Zimmermann, S. (2007). Mosaic of thought: The power of comprehension strategy instruction (2nd ed.). Portsmouth, $\mathrm{NH}$ : Heinemann.
Moje, E.B. (2008). Foregrounding the disciplines in secondary literacy teaching and learning: A call for change. Journal of Adolescent \& Adult Literacy, 52(2), 96-107. doi:10.1598/ JAAL.52.2.1

Moje, E.B., \& Speyer, J. (2008). The reality of challenging texts in high school science and social studies: How teachers can mediate comprehension. In K.A. Hinchman \& H.K. Sheridan-Thomas (Eds.), Best practices in adolescent literacy instruction (pp. 185-211). New York: Guilford.

Moore, D.W., Bean, T.W., Birdyshaw, D., \& Rycik, J.A. (1999). Adolescent literacy: A position statement. Journal of Adolescent E Adult Literacy, 43(1), 97-112.

O’Halloran, K.L. (2005). Mathematical discourse: Language, symbolism, and visual images. London: Continuum.

Perie, M., Grigg, W.S., \& Donahue, P.L. (2005). The nation's report card: Reading 2005 (NCES 2006-451). Washington, DC: U.S. Department of Education.

Schleppegrell, M.J. (2004). The language of schooling: A functional linguistics perspective. Mahwah, NJ: Erlbaum.

Shanahan, T., \& Shanahan, C. (2008). Teaching disciplinary literacy to adolescents: Rethinking content area literacy. Harvard Educational Review, 78(1), 40-61.

Tovani, C. (2000). I read it, but I don't get it: Comprehension strategies for adolescent readers. Portland, ME: Stenhouse.

Vacca, R.T., \& Vacca, J.L. (2005). Content area reading: Literacy and learning across the curriculum. Boston: Allyn \& Bacon.

\section{Literature Cited}

Behr, E. (1996). Prohibition: Thirteen years that changed America. New York: Arcade.

Howe, D., \& Howe, J. (1979). Bunnicula: A rabbit tale of mystery. New York: Scholastic.

Modern Biology. (2006). Columbus, OH: Glencoe.

Science explorer: Life science. (2001). Upper Saddle River, NJ: Prentice Hall.

Fang teaches at the University of Florida, Gainesville, USA; e-mail zfang@coe.ufl.edu. Schleppegrell teaches at the University of Michigan, Ann Arbor, USA; e-mail mjschlep@umich.edu. 